\title{
Pengaruh Strategi Pembelajaran Problem Solving Berbasis Mind mapping Terhadap Keterampilan Berpikir Kritis Siswa Kelas XI SMA Negeri 7 Palu
}

\author{
Moh.Astiar Syuhudi, Marungkil Pasaribu dan Muhammad Jarnawi \\ Astiarsyuhudi@gmail.com \\ Program Studi Pendidikan Fisika FKIP Universitas Tadulako \\ Jl. Soekarno Hatta Km. 9 Kampus Bumi Tadulako Tondo Palu - Sulawesi Tengah
}

\begin{abstract}
Abstrak - Pembelajaran problem solving (pemecahan masalah) adalah suatu cara menyajikan pelajaran dengan mendorong siswa untuk mencari dan memecahkan suatu masalah atau persoalan dalam rangka untuk mencapai tujuan pembelajaran. Mind mapping adalah salah satu cara mencatat materi pelajaran yang memudahkan siswa belajar. Tujuan Penelitian ini untuk menguji signifikasi perbedaan keterampilan berpikir kritis siswa yang diberi perlakuan menggunakan strategi pembelajaran problem solving berbasis Mind Maping dengan yang diberi perlakuan menggunakan strategi pembelajaran problem solving pada siswa kelas XI SMA Negeri 7 Palu. Metode yang digunakan adalah eksperimen kuasi dengan equivalent pretest-posttest design. Populasi penelitian ini adalah seluruh siswa kelas XI SMA Negeri 7 Palu. Teknik pengambilan sampel adalah purposive sampling. Kelas XI IPA 3 yang berjumlah 30 orang terpilih sebagai kelas eksperimen dan kelas XI IPA yang berjumlah 28 orang terpilih sebagai kelas kontrol. Instrumen yang digunakan berupa tes keterampilan berpikir kritis berbentuk essay berjumlah 5 soal yang telah divalidasi, setiap unit soal mengukur satu indikator keterampilan berpikir kritis yaitu keterampilan menganalisis, keterampilan mensintesis, keterampilan mengenal dan memecahkan masalah, keterampilan menyimpulkan serta keterampilan mengevaluasi atau menilai. Berdasarkan hasil pengolahan data, diperoleh rerata skor post-test kelas eksperimen sebesar 20,10 dan kelas kontrol sebesar 16, 11. Analisis data dengan teknik statistik uji-t dua pihak diperoleh nilai thitung $=6,24$ dan nilai $t_{\text {tabel }}$ adalah $t_{0,95(56)}=2,02$. Hal ini berarti, nilai thitung berada diluar daerah penerimaan $\mathrm{H}_{0}$. Hasil ini menyatakan terdapat perbedaan keterampilan berpikir kritis antara kelas yang diberi perlakuan dengan strategi pembelajaran problem solving berbasis Mind Maping dengan kelas yang diberi perlakuan strategi pembelajaran problem solving.
\end{abstract}

Kata Kunci: Problem solving, Mind mapping, Keterampilan Berpikir Kritis.

\section{PENDAHULUAN}

Seiring dengan perkembangan zaman, kehidupan dewasa ini membutuhkan manusiamanusia yang cerdas dan memiliki daya saing. Sehingga pengetahuan yang diperoleh dari bangku sekolah sudah seharusnya mengajarkan pengetahuan dan keterampilan yang bermakna bagi siswa dalam kehidupan nyata. Agar terjadi pengkontruksian pengetahuan secara bermakna, guru haruslah melatih siswa agar berpikir secara kritis dalam menganalisis maupun dalam memecahkan suatu permasalahan.

Dalam dunia sekarang ini, berpikir kritis dan pemecahan masalah adalah salah satu keterampilan utama yang harus dimiliki oleh setiap individu. Dalam hal ini, salah satu tujuan pendidikan modern adalah untuk menumbuhkan individu yang tahu apa yang mereka pelajari dan mengapa mereka belajar bukan hanya mendapat informasi langsung dan membangun pengetahuan mereka sendiri. Menumbuhkan individu yang dapat memecahkan masalah yang dihadapi, memperoleh informasi baru dengan menggunakan informasi yang ia belajar, tahu dan berpikir seperti berpikir kritis, berpikir kreatif, dan sejalan juga di antara tujuan tersebut. Dari perspektif ini, salah satu fungsi yang paling penting dari sistem pendidikan saat ini adalah untuk memberikan individu dengan pemikiran yang kritis dan keterampilan pemecahan masalah [1].

Guru dalam mengajarkan pelajaran Fisika disekolah masih sering menggunakan model pembelajaran yang didominasi dengan ceramah, sehingga kemampuan siswa dalam berpikir kritis sulit untuk dikembangkan. Pembelajaran yang menggunakan metode ceramah belum memberikan dampak yang baik dalam meningkakan keterampilan berpikir siswa, dikarenakan siswa hanya mendengarkan ceramah dari guru yang membuat siswa menjadi pasif. Sehingga berdampak pada keterampilan berpikir siswa menjadi lambat dan rendah. [2]. Hal ini sejalan dengan Rofiudin [3] menyatakan bahwa terjadinya keluhan tentang rendahnya keterampilan berpikir kritis lulusan dasar sampai perguruan tinggi di Indonesia karena proses pembelajaran yang dapat 
meningkakan kemampuan berpikir kritis belum di tangani dengan baik.

Salah satu strategi pembelajaran yang dapat meningkakan keterampilan berpikir kritis adalah strategi pembelajaran Problem Solving. Dalam penerapan pembelajaran Problem Solving siswa lebih banyak berdiskusi dan bekerjasama dengan kelompoknya dibandingkan dengan mendengarkan penjelasan materi dari guru.

Pembelajaran kolaboratif melalui problem solving terbukti dapat memajukan proses pembelajaran fisika dan keaktifan siswa, Siswa terlibat secara aktif dalam proses diskusi, saling bertukar pendapat dan ide-ide yang mereka miliki antar anggota kelompok untuk menemukan solusi bagi permasalahan yang mereka diskusikan [4]. Problem solving dapat meningkatkan kemampuan berpikir kritis, siswa menjadi lebih kritis, baik itu dalam mengeluarkan pendapat, bertanya, mengidentifikasi, maupun memecahkan masalah yang ada [5]. Dalam pembelajaran problem solving siswa diarahkan melakukan penyelidikan untuk mencari penyelesaian terhadap masalah yang diberikan. Siswa menganalisis, mendefinisikan masalah, mengumpulkan informasi, mengumpulkan referensi, sampai dengan merumuskan kesimpulan [6].

Pelaksanaan problem solving memiliki kekurangan antara lain: 1). Memerlukan cukup banyak waktu, 2). Melibatkan kebih banyak orang, 3).Tidak efektif jika terdapat beberapa siswa yang pasif, 4). Memerlukan perencanaan yang teratur dan matang, 5). Tidak semua materi pelajaran mengandung masalah. Sehingga tidak maksimalnya pelaksanaan tahapan-tahapan Strategi pembelajaran problem solving yang berdampak pada peningkatan keterampilan berpikir kritis siswa tidak maksimal. Untuk menutupi atau menetralisir kekurangan - kekurangan tersebut dapat dikombinasikan atau digabungkan dengan metode pembelajaran.

Salah satu metode pembelajaran yang juga dapa meningkatkan keterampilan berpikir kritis siswa adalah metode mind mapping. Menurut Ristiasari, dkk. Metode mind mapping adalah metode mencatat kreatif yang memudahkan kita mengingat banyak informasi, meningkatkan kemampuan siswa dalam berpikir karena memadukan dan mengembangkan potensi kerja otak, sehingga perhatian terpusat pada subjek serta mampu mengembangkan cara pengaturan pikiran secara terperinci [6].

Model pembelajaran kooperatif tipe Metode Numbered Heads Together (NHT) berbasis mind mapping memberikan prestasi belajar yang lebih baik dibandingkan model pembelajaran kooperatif tipe NHT dan model pembelajaran langsung [7]. Model pembelajaran kooperatif tipe Student Team Achievement Devision (STAD) berbasis mind mapping memberikan peningkatan yang signifikansi terhadap kemampuan berpikir kritis siswa dibandingkan model pembelajaran kooperatif tipe STAD pada materi Gerak lurus [8].

Berdasarkan pada uraian latar belakang di atas maka peneliti bermaksud akan meneliti pengaruh keterampilan berpikir kritis siswa yang di beri perlakuan strategi pembelajaran problem solving berbasis mind mapping dengan kelompok siswa yang di berikan perlakuan strategi Pembelajaran Problem Solving yang akan dilaksanakan pada siswa Kelas XI SMA Negeri 7Palu, pada materi Termodinamika

\section{METODE PENELITIAN}

Penelitian yang digunakan adalah jenis penelitian dengan rancangan eksperimen kuasi (quasi-experimental design)[9].

Desain penelitian yang digunakan yaitu the equivalent pretest-posttest design[10]. Desain penelitian yang digunakan dapat dilukiskan seperti pada tabel 1 .

\begin{tabular}{cccc}
\multicolumn{4}{c}{ TABEL 1 DESAIN PENELITIAN } \\
\hline Kelompok & Pre- test & Perlakuan & Post-test \\
\hline Eksperimen & $\mathrm{O}_{1}$ & $\mathrm{X}$ & $\mathrm{O}_{1}$ \\
Kontrol & $\mathrm{O}_{1}$ & & $\mathrm{O}_{1}$
\end{tabular}

Keterangan:

$\mathrm{X}$ : Strategi pembelajaran problem solving berbasis mind mapping

$\mathrm{O}_{1}$ : Tes awal dan tes akhir

Penelitian dilakukan di SMA Negeri 7 Palu. Populasinya adalah seluruh siswa kelas XI tahun pelajaran 2017/2018. Sampel dalam penelitian ini diperoleh secara purposive sampling yaitu kelas XI IPA 3 yang berjumlah 30 siswa sebagai kelas eksperimen yang diberikan perlakuan Strategi pembelajaran Problem Solving berbasis mind mapping dan kelas $\mathrm{XI}$ $\mathrm{IPA}_{4}$ yang berjumlah 28 siswa sebagai kelas kontrol yang diberikan perlakuan Strategi pembelajaran Problem Solving. Teknik pengambilan sampel yang digunakan adalah purposive sampling, yaitu teknik penentuan sampel dengan pertimbangan tertentu.

Instrumen yang digunakan untuk melihat keterampilan berpikir kritis siswa. Tes yang digunakan berupa tes essay sebanyak 5 item soal yang dilakukan sebanyak dua kali pengujian, yaitu pada tahap awal sebelum 
perlakuan (pre-test) dan tahap akhir setelah perlakuan (post-test). Tes ini sebelumnya di validasi oleh validator ahli.

Data yang diperoleh dari penelitian ini selanjutnya diolah dengan menggunakan uji statistik berupa uji normalitas (Chi kuadrat), uji homogenitas (Fisher), dan uji hipotesis (uji-t dua pihak).

\section{HASIL DAN PEMBAHASAN}

\section{A. Hasil Penelitian}

Hasil pengolahan data pre-test dan post-test untuk masing-masing kelas yaitu kelas eksperimen dan kelas kontrol, diperoleh nilai maksimum, nilai minimum, nilai rata-rata dan simpangan baku seperti terlihat pada Tabel 2 .

TABEL 2 DESKRIPSI SKOR TES KETERAMPILAN BERPIKIR KRITIS SISWA UNTUK KELAS EKSPERIMEN DAN KELAS KONTROL

\begin{tabular}{lcccc}
\hline & \multicolumn{2}{c}{ Pre-test } & \multicolumn{2}{c}{ Post-test } \\
\cline { 2 - 5 } Uraian & Eksperimen & Kontrol & Eksperimen & Kontrol \\
\hline $\begin{array}{l}\text { Sampel } \\
(\mathrm{n})\end{array}$ & 30 & 28 & 30 & 28 \\
$\begin{array}{l}\text { Skori } \\
\text { maksimum }\end{array}$ & 13 & 12 & 24 & 22 \\
$\begin{array}{l}\text { Skor } \\
\text { minimum }\end{array}$ & 2 & 2 & 14 & 11 \\
$\begin{array}{l}\text { Skor rata- } \\
\text { rata }\end{array}$ & 7,83 & 6,86 & 20,10 & 16,11 \\
$\begin{array}{l}\text { Standar } \\
\text { deviasi }\end{array}$ & 2,72 & 2,44 & 2,31 & 2,53 \\
\hline
\end{tabular}

Hasil pengujian normalitas menggunakan uji Chi-kuadrat dengan kriteria penerimaan $\mathrm{X}^{2}$ Hitung $<x^{2}$ tabel, taraf signifikansi $a=0,05$ dan derajat kebebasan $\mathrm{dk}=\mathrm{k}-3$. Berdasarkan hasil perhitungan skor pre-test nilai $\chi^{2}$ hitung untuk kelas eksperimen adalah 0,51 dan untuk kelas kontrol adalah 1,89 dengan $\chi^{2}$ tabel sebesar 7,81 . Data tersebut disajikan pada tabel 3 .

TABEL 3 HASIL UJI NORMALITAS PRE-TEST KELAS EKSPERIMEN DAN KELAS KONTROL

\begin{tabular}{lllll}
\hline No. & Kelas & $\begin{array}{l}\text { Nilai } \\
X^{2} \text { Hitung }\end{array}$ & $\begin{array}{l}\text { Nilai } \\
\mathrm{X}^{2} \text { Tabel } \\
(\mathrm{a}=105)\end{array}$ & Keputusan \\
\hline 1 & Eksperimen & 0,51 & & $\begin{array}{l}\text { Terdistribusi } \\
\text { normal } \\
\text { Terdistribusi } \\
\text { normal }\end{array}$ \\
\hline
\end{tabular}

Berdasarkan hasil uji normalitas pada Tabel 3 diketahui nilai $X^{2}$ Hitung $<X^{2}$ tabel sehingga dapat dinyatakan kedua kelas berasal dari populasi yang terdistribusi normal.

Uji homogenitas pada penelitian ini menggunakan uji statistik Fisher (Uji F) dengan taraf signifikansi $a=0,05$. Uji homogenitas dilakukan untuk melihat apakah data berasal dari varians yang sama atau tidak. Data tersebut disajikan pada tabel 4.

TABEL 4 HOMOGENITAS DUA VARIANS TES AKHIR (PRE

\begin{tabular}{cccc}
\multicolumn{2}{c}{$T E S T)$ KELAS EKPERIMEN DAN KELAS KONTROL. } \\
\hline $\begin{array}{c}\text { Varians } \\
\text { hitung }\end{array}$ & $\begin{array}{l}\text { Nilai } \\
0,05)\end{array}$ & table $(\mathrm{a}=$ & Keputusan \\
\hline 1,07 & & 1,87 & Data homogen \\
\hline
\end{tabular}

Berdasarkan hasil uji homogenitas pada Tabel 4 dengan taraf signifikansi $(a=0,05)$, dari data tersebut terlihat bahwa Fhitung $(1,07)$ $<$ Ftabel (1.87) maka berdasarkan kriteria pengambilan keputusan dapat dinyatakan bahwa tidak terdapat perbedaan varians antara kelas eksperimen dan kelas kontrol atau dengan kata lain varians antara kelas eksperimen dan kelas kontrol adalah sama atau homogen.

Uji t yang digunakan untuk hipotesis ini adalah uji-t dua pihak. Uji ini digunakan untuk memastikan apakah hipotesis yang diajukan dapat diterima atau ditolak. Uji $t$ tersebut diperoleh berdasarkan data skor pre-test dan post-test. Data tersebut disajikan pada tabel 5 dan 6.

TABEL 5 UJI BEDA RATA-RATA (DUA PIHAK) PRE-TEST KELAS EKSPERIMEN DAN KELAS KONTROL

\begin{tabular}{cccccc}
\hline No. & Kelas & $\begin{array}{c}\text { Nilai rata- } \\
\text { rata } \\
(\bar{X})\end{array}$ & $\mathrm{t}_{\text {hitung }}$ & $\begin{array}{c}\mathrm{t} \\
\text { table }\end{array}$ & Keputusan \\
\hline 1 & Eksperimen & 7,83 & & & $\mathrm{H}_{0}$ \\
2 & Kontrol & 6,86 & 1,42 & 2,02 & \begin{tabular}{c} 
diterima \\
\hline
\end{tabular} \\
\hline
\end{tabular}

Berdasarkan data pada tabel 5 terlihat bahwa thitung $(1,42)<t_{\text {tabel }}(2,02)$. Nilai thitung berada pada daerah penerimaan $\mathrm{H}_{0}$. Dengan demikian $\mathrm{H}_{0}$ diterima dan $\mathrm{H}_{1}$ ditolak. Hal ini menyatakan sebelum diberi perlakuan tidak terdapat perbedaan keterampilan berpikir kritis antara kelas XI IPA 3 (kelas eksperimen) dengan kelas XI IPA 4 (kelas kontol).

TABEL 6 UJI BEDA RATA-RATA (DUA PIHAK) POST-TEST KELAS EKSPERIMEN DAN KELAS KONTROL

\begin{tabular}{cccccc}
\hline No. & Kelas & $\begin{array}{c}\text { Nilai } \\
\text { rata-rata } \\
(\bar{X})\end{array}$ & $\mathrm{t}_{\text {hitung }}$ & $\begin{array}{c}\mathrm{t} \\
\text { table }\end{array}$ & Keputusan \\
\hline 1 & Eksperimen & 20,10 & & & $\mathrm{H}_{1}$ \\
2 & Kontrol & 16,11 & & & diterima
\end{tabular}

Hasil uji beda rata-rata setelah diberi perlakuan dapat dilihat pada tabel 6 . Berdasarkan data pada tabel 6 thitung $(6,24)>$ 
tabel $(2,02)$. Hal ini berarti, nilai thitung berada diluar daerah penerimaan $H$. Hasil ini menyatakan terdapat perbedaan keterampilan berpikir kritis antara kelas yang diberi perlakuan dengan Strategi pembelajaran Problem Solving. berbasis mind mapping dengan kelas yang diberi perlakuan Strategi pembelajaran Problem Solving.

\section{B. Pembahasan}

Dari hasil uji normalitas, homogenitas dan hipotesis diperoleh data bahwa keadaan awal siswa yang dijadikan sampel pada penelitian ini terdistribusi normal, homogen dan tidak ada perbedaan dari segi pengetahuan sehingga dapat digunakan sebagai sampel. Adapun Hasil analisis data pre-test untuk kelas kontrol rerata skor yang diperoleh adalah 6,86 dengan standar deviasi 2,44 dan daya serap 27,43\% yang termasuk kategori sangat kurang kritis. sedangkan kelas eksperimen rerata skor yang diperoleh adalah 7,83 dengan standar deviasi 2,72 dan daya serap $31,33 \%$ yang termasuk kategori sangat kurang kritis.

Hasil uji-t dua pihak diketahui bahwa kedua kelas yang dijadikan sampel penelitian sebelum diberikan perlakuan memiliki kemampuan keterampilan berpikir kritis yang sama. Selanjutnya diberikan perlakuan pada kedua kelas yaitu kelas eksperimen dengan Strategi pembelajaran problem solving berbasis mind mapping dan pada kelas kontrol dengan Strategi pembelajaran problem solving. Setelah diberikan perlakuan pada kedua kelas peneliti memberikan post-test (tes akhir). Berdasarkan hasil pada post-test, diperoleh rerata skor untuk kelas kontrol adalah 16,11 dengan standar deviasi 2,53 dan daya serap 64,43\% yang termasuk kategori cukup kritis. Sedangkan rerata skor untuk kelas eksperimen adalah 20,10 dengan standar deviasi 2,31 dan daya serap $80,40 \%$ yang termasuk kategori kritis.

Secara kualitatif berdasarkan perhitungan daya serap menunjukkan bahwa setelah diberikan perlakuan pada kedua kelas yaitu kelas eksperimen dan kelas kontrol terjadi peningkatan keterampilan berpikir kritis siswa. Akan tetapi peningkatan keterampilan berpikir kritis siswa pada kelas eksperimen lebih tinggi (sangat kurang kritis menjadi kritis). Dibandingkan keterampilan berpikir kritis siswa kelas kontrol (sangat kurang kritis menjadi cukup kritis). Hal ini diduga karena pada kelas eksperimen diberikan perlakuan dengan menerapkan Strategi pembelajaran problem solving berbasis mind mapping sedangkan pada kelas kontrol di berikan perlakuan dengan Strategi pembelajaran problem solving tanpa berbasis mind mapping. Sehingga dapat disimpulkan bahwa pembelajaran dengan menerapkan Strategi pembelajaran problem solving berbasis mind mapping lebih besar pengaruhnya dalam meningkatkan keterampilan berpikir kritis siswa dibandingkan Strategi pembelajaran problem solving tanpa berbasis mind mapping.

Pada penelitian ini kedua kelas yang dijadikan sampel penelitian sama-sama menggunakan Strategi pembelajaran problem solving yang memenuhi 4 langkah pokok tersebut, hanya saja pada kelas eksperimen Strategi pembelajaran problem solving di kombinasikan dengan mind mapping sehingga sedikit berbeda dengan pembelajaran yang ada pada kelas kontrol tetapi perbedaannya hanya terletak pada proses dari tahapan pembelajaran yang ada pada kelas eksperimen.

Terdapat perbedaan antara kelas kontrol dan eksperimen, dimana sebelum mengerjakan lembar kerja siswa (LKS) tentang termodinamika pada kelas eksperimen masing -masing kelompok diberikan tugas untuk membuat mind mapping dari materi yang saat itu di ajarkan sedangkan pada kelas kontrol tidak. Misalnya pada pertemuan pertama yakni materi usaha dan proses dalam termodinamika, jadi siswa harus menbuat materi tersebut dalam bentuk mind mapping. Tujuan dari membuat mind mapping adalah untuk memudahkan siswa dalam mempelajari materi dan membantu mereka saat mencari referensi untuk menyelesaikan masalah yang terdapat dalam lembar kerja siswa (LKS) tentang termodinamika.

Langkah pertama yaitu memahami masalah dimana pada langkah ini siswa harus mengidentifikasi unsur-unsur dalam soal dan menemukan inti dari permasalahan yang di berikan. Setelah siswa diberikan sebuah masalah dalam bentuk LKS tentang termodinamika yang harus diselesaikan bersama teman - teman kelompoknya, maka selajutnya siswa harus memahami dan menemukan inti dari permasalahan tersebut. Langkah pertama ini dilakukan di kedua kelas yaitu eksperimen dan kelas control.

Langkah kedua yaitu menyusun rencana penyelesaian. Pada tahap ini siswa telah mengidentifikasi dan menemukan masalah serta menyusun cara untuk menyelesaikan masalah tersebut. Pada tahap ini dilakukan di kedua kelas yang dijadikan sampel penelitian yakni kelas eksperimen dan kelas kontrol. Pada kelas eksperimen terlihat siswa dalam tahap ini lebih cepat dan tepat dalam menemukan masalah yang terdapat dalam LKS tentang termodinamika serta menyusun cara untuk 
p-ISSN 2338-3240, e-ISSN 2580-5924

menyelesaikan, sedangkan pada kelas kontrol siswa lebih lambat dan sedikit susah dalam menemukan masalah yang terdapat dalam LKS.

Langkah ketiga yaitu melaksanakan rencana penyelesaian. Pada tahap ini siswa menyelesaikan masalah yang telah diberikan dalam bentuk lembar kerja siswa (LKS) tentang termodinamika dengan melihat buku, ineternet dan referensi lain. Pada tahap ini terdapat perbedaan antara kelas eksperimen dan kontrol. Dimana pada kelas eksperimen, dalam menyelesaikan masalah tersebut referensi yang mereka gunakan adalah mind mapping tentang materi termodinamika yang telah mereka kerajakan, sedangkan untuk kelas kontrol referensi yang mereka gunakan hanyalah buku.

Pada tahap ini terlihat perbedaan antara kelas eksperimen dan kontrol dalam menyelesaikan masalah yang diberikan. Dimana pada kelas eksperimen durasi waktu yang digunakan dalam menyelesaikan soal-soal dalam lembar kerja siswa (LKS) tentang termodinamika lebih cepat jika dibandingkan dengan kelas kontrol. Hal ini dikarenakan pada kelas eksperimen, mereka menggunakan mind mapping tentang materi hukum I termodinamika dimana semua materi yang di pelajari telah diringkas menjadi satu sehingga tidak terlalu sulit bagi mereka untuk menemukan jawaban dari soal-soal yang ada serta pemahaman mereka terhadap materi tersebut dapat dikatakan baik.sedangkan pada kelas kontrol terlihat mereka sedikit susah dan lama dalam menemukan jawaban dari soalsoal yang diberikan dan pemahaman mereka ada materi tersebut masih kurang sehingga mereka perlu memahami materinya terlebih dahulu.

Langkah keempat yaitu memeriksa kembali penyelesaian yang telah dilaksanakan. Pada tahap ini siswa mengulang kembali atau memeriksa kembali jawaban yang telah dikerjakan, kemudian bersama- sama guru menyimpulkan dan siswa mempresentasikan dalam kelas. Pada saat masing- masing kelompok mempresentasikan mind mapping dan jawaban mereka, sedangkan kelompok lain diberi kesempatan untuk menanggapi. Pada kelas eksperimen, terjadi suasana diskusi yang hidup dan siswa terlihat aktif .Sedangakan pada kelas kontrol tidak demikian.

Berdasarkan data peningkatan setiap indikator Keterampilan Berpikir Kritis pada kelas eksperimen dan kelas kontrol dapat dikatakan bahwa Empat langkah pada pembelajaran problem solving yang di terapkan pada kelas eksperimen dan kelas kontrol berpengaruh dalam meningkatkan indikatorindikator keterampilan berpikir kritis yaitu keterampilan menganalisis, keterampilan mensintesis, keterampilan mengenal dan memecahkan masalah, keterampilan menyimpulkan dan keterampilan mengevaluasi atau menilai. Akan tetapi strategi pembelajaran problem solving berbasis mind mapping lebih baik dalam meningkakan setiap indikator Keterampilan Berpikir Kritis dibandingkan strategi pembelajaran problem solving.

Berdasarkan penelitian yang dilakukan, penerapan mind mapping pada pembelajaran problem solving memiliki kelebihan seperti (1) siswa lebih cepat dalam menyelesaikan masalah-masalah yang diberikan, (2) membantu siswa memahami materi dengan mudah dalam proses belajar, (3) memudahkan siswa dalam mengingat kembali materi yang dielajari .Sehingga secara kuantitatif yang diperoleh dari hasil analisis data, rata-rata perubahan keterampilan berpikir kritis siswa dikelas ekseperimen lebih tinggi dari pada kelas kontrol. Hal ini menunjukkan bahwa pemberian strategi pembelajaran problem solving berbasis mind mapping lebih berpengaruh terhadap keterampilan berpikir kritis siswa dibandingkan dengan strategi pembelajaran problem solving yang diberikan di kelas kontrol pada materi termodinamika.

Penelitian ini sejalan dengan penelitian yang sebelumnya dilakukan oleh Darmawan (2010). yang menemukan bahwa Problem solving dapat meningkatkan kemampuan berpikir kritis, siswa menjadi lebih kritis, baik itu dalam mengeluarkan pendapat, bertanya, mengidentifikasi, maupun memecahkan masalah yang ada. Galuh (2009) yang menemukan bahwa keterampilan berkomunikasi dan berpikir kritis siswa dalam belajar matematika dengan metode pembelajaran mind mapping terjadi peningkatan secara signifikan.Ristiasari, dkk (2012) yang menemukan bahwa bahwa penerapan model pembelajaran problem solving dengan mind mapping berpengaruh terhadap kemampuan berpikir kritis di SMP Negeri 6 Temanggung.

\section{KESIMPULAN DAN SARAN}

Hasil analisis data untuk kelas kontrol diperoleh rerata skor sebesar 16,11 dengan standar deviasi 2,53 dan daya serap $64,43 \%$ berada pada kategori cukup kritis. Kelas eksperimen memperoleh rerata skor sebesar 20,10 dengan standar deviasi 2,31 dan daya serap $80,40 \%$ berada pada kategori kritis. Dari hasil uji-t dua pihak menunjukkan tabel $(-2,02)$ $<$ thitung $(6,24)<$ tabel $(2,02)$, yang berarti thitung $(6,24)$ berada diluar daerah penerimaan $\mathrm{H}_{0}$. hal 
ini menunjukkan terdapat perbedaan keterampilan berpikir kritis antara siswa yang diberi strategi pembelajaran problem solving berbasis mind mapping dan siswa yang hanya diberi Sehingga strategi pembelajaran problem solving. sehingga dapat disimpulkan bahwa terdapat pengaruh yang signifikansi strategi pembelajaran problem solving berbasis mind mapping terhadap keterampilan berpikir kritis siswa kelas XI SMA Negeri 7 Palu.

Berdasarkan kesimpulan ada beberapa saran yang dapat dikemukakan:(1) Disarankan kepada tenaga pendidik khususnya guru kiranya dapat mempertimbangkan strategi pembelajaran problem solving berbasis Mind mapping sebagai salah satu alternatif dalam usaha untuk meningkatkan meningkatkan keterampilan berpikir kritis siswa, (2) peneliti lebih memperhatikan setiap langkah-langkah pembelajaran problem solving dengan baik dan siswa yang menjadi objek penelitian harurslah mengetahui cara membua mind mapping yang benar, agar tidak menjadi kendala pada saat penelitian. (3) Peneliti berharap ada penelitianpenelitian selanjutnya menggunakan strategi pembelajaran problem solving berbasis mind mapping pada konsep atau materi fisika yang lain.

\section{DAFTAR PUSTAKA}

[1] Polat, RH \& Tümkaya, S. (2010). An investigation of the students of primary school problem solving abilities dependin gonneed for cognition. Elementary Education Online, 9 (1), 346-360.

[2] Yustina, S., Irhasyuarna, Y., \& Kusasi, M. (2015). Penerapan Metode Pembelajaran Problem Solving Terhadap Kemampuan Berpikir Kritis Siswa Pada Materi Koloid Kelas XI IPA SMA Negeri 4 Banjarmasin. Quantum, Jurnal Inovasi Pendidikan Sains,6 (2).

[3] Rofi'udin. (2000). Model Pendidikan Berpikir Kritis Kreatif Untuk Siswa Sekolah Dasar. Majalah Bahasa dan Seni, 1(28): 72:94

[4] Sudiarta, I.G. (2009). Pengembangan Pembelajaran Berpendekatan Tematik Berorientasi Pemecahan Masalah Matematika Terbuka Untuk Mengembangkan Kompetensi Berpikir Divergen, Kritis, Dan Kreatif. Jurnal Pendidikan dan Pengajaran UNDIKSHA. 2 (4):373-392.

[5] Darmawan. (2010). Penggunaan pembelajaran berbasis masalah dalam meningkatkan kemampuan berpikir kritis siswa pada pembelajaran IPS di MI Darrusaadah.

[6] Ristiasari, T., Priyono, B., \& Sukaesih, S. (2012). Model Pembelajaran Problem Solving dengan Mind Mapping terhadap Kemampuan Berpikir Kritis Siswa. Journal of Biology Education, 1(3).

[7] Wahyu Utomo., Mardiyana dan Tri Atmojo K. (2015). Eksperimentasi Model Pembelajaran Kooperatif Tipe Numbered Head Together (NHT) Berbasis Mind Mapping Ditinjau Dari Gaya Belajar Siswa Kelas VII SMP Negeri Se-Kabupaten Pacitan Tahun Pelajaran 2013/2014. Jurnal Elektronik Pembelajaran Matematika, Vol 3, No. 2, Hal. 134-136.

[8] Lapasere, S. (2016) Pengaruh Model Pembelajaran Kooperatif Tipe Stad Berbasis Mind Mapping Terhadap Keterampilan Berpikir Kritis Pada Konsep Gerak Lurus Siswa Kelas X Sma Negeri 1 Ampibabo. Program Studi Pendidikan Fisika FKIP UNTAD.

[9] Sukmadinata, N. (2010). Metode Penelitian Pendidikan. Bandung: PT. Remaja Rosdakarya

[10] Sugiyono. (2006). Metode Penelitian Pendidikan Pendekatan Kuantitatif, Kualitatif, dan R\&D. Bandung: Alfabeta. 